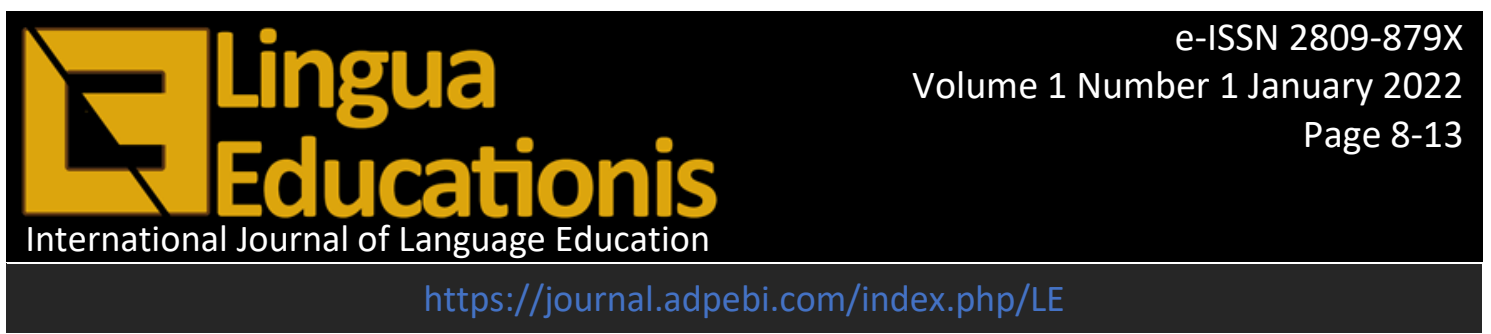

\title{
AN ANALYSIS OF INFLECTIONAL AFFIXES IN THE RAINBOW TROOPS NOVEL BY ANDREA HIRATA TRANSLATED BY ANGIE KILBANE
}

\author{
Erna Habibah', Zumrotul Muniroh² \\ Universitas Indraprasta PGRI, Jakarta, Indonesia \\ Email habibah.rzk.jkt@gamil.com ${ }^{1}$, zumrotul.muniroh22@gmail.com².
}

Diserahkan: 10-12-2021 Direviu: 05-01-2022 $\quad$ Diterima: 15-12-2022 $\quad$ Diterbitkan: 20-01-2022

\begin{abstract}
This research aims to analyze the types and function of inflectional affixes in The Rainbow Troops Novel by Andrea Hirata Translated by Angie Kilbane. The research is also as a reference for reader to enrich their knowledge about inflectional affixes. The data of research contain kinds of type and functions of inflectional affixes in The rainbow Troops Novel. The researcher uses descriptive qualitative method in analyzing the data. The data are analyzed based on Yule and Fromkin et.al categories of inflectional affixes. The researcher collects, identifies, classifies and presents data into tables accordance to the function. The result of the research shows that there are four types of inflectional verbs and two types of inflectional adjectives are used in the novel. The most dominant type of inflectional affixes used in the novel is inflectional verbs of past tense in regular form with total 640(44.5\%), which are followed inflectional verbs of past participle in regular form with total $313(21.78 \%)$. Then, inflectional verbs of present participle are $235(16.34 \%)$, which are followed inflectional verbs in irregular form for past tense with total 90(6.25\%) and irregular form of past participle with total $80(5.56 \%)$. The inflectional adjectives are $20(1.39 \%)$ for comparative adjective and $30(2.09 \%)$ for superlative adjective. The result above shows that inflectional affixes are important to be studied to enrich vocabulary in mastering English for the reader.
\end{abstract}

Keywords: Inflectional Affixes, Types of inflectional affixes, function of inflectional affixes, The Rainbow Troops Novel

This work is licensed under a Creative Commons Attribution 4.0 International License.

\section{Introduction}

Humans are constantly studying how to do something through language, how to construct meaning through word choices and grammatical sources. The language we use always produces meaning because in language there is a message that is conveyed. Language is not only a means of communication, but also a tool for carrying out social practices or doing something. Language is a tool used by humans to communicate with each other to express their thoughts, feelings, and emotions. Language is a guide to "social realitye. Though language is not ordinarily thought of essential interest to the students of social science, it is powerful condition about social problems and processes. Human 
beings do not live in the objective world alone but they are very much at the mercy of the particular language which has become the medium of expression for their society.

English is one of the languages which needed by the world community. This is understandable because English appears to be the world's language with a very wide spread of spoken areas. Indonesia is a country that has an interest in English language. Moreover, the dissemination of information is carried out through the English language media. Thus, English become the first foreign language that needed to be mastered, by society. In Indonesia, English has long been taught in junior high schools (SMP), senior high schools (SMA), and universities (PT). Even today, in some places English is given at the primary school level. This shows that English is very important and needs to be mastered by students for the benefit of science. Considering the importance of English, it has been firmed as one of the compulsory subject to be taught to the student. In the newest of Indonesian education curriculum 2013, English is taught at school starting from the junior high school up to university. It consists of four skills which are listening, speaking, reading and writing. To gain the four-skill, we should fulfill the language components such the knowledge structure, pronunciation, spelling and vocabulary.

One of the characteristics of the English concerns about the inflective nature of language. This is different from Indonesian which is agglutinative. With regard to verbs, for example, English has a system of conjugations which is related to the temporal. Thus, the use of language verbs English is heavily influenced by the tense. Indonesian does not recognize time that causing verb change. Mistakes like this are not only found in those who are learning English at the beginner level, but they are also found at the tertiary level.

One of the literary genres in the form of prose is novel. Novel is a long prose essay containing a series of stories of a person's life with the people around him by highlighting the character and nature of each actor. Interpretation of the character, traits, and personal qualities of a character is very much based on what is said and what is done. The novel contains events that appear with the character as the actor. One of the good novel is Laskar Pelangi. Laskar Pelangi is one of Andrea Hirata's work which always receives good appreciation from readers. Andrea Hirata's popularity rose after published this novel. Hirata has also received many awards, such as the winner of the New York Book Festival 2013, in the General Fiction category, for the Rainbow Troops or the American edition of Laskar Pelangi that translated by Angie Kilbane.

As literary work, a novel is interesting to be studied. The study of language and its structure is linguistic, including studying grammar, syntax, and phonetics. In linguistics, words are studied in a branch of linguistics called morphology.

Morphology is the study of the internal structure of words. Morphology is a study of arrangement of morpheme and also study of the parts in morphemes, allomorphs, and affixes. One of the characteristics of agglutination type language is the formation of more words through affixing (affixation). The affix (affix) can be attached at the beginning of the basic form (prefix), in the middle of the basic form (infixation), at the end of the basic form (suffix), or prefix and suffix can be attached simultaneously to the basic form affixation. Fromkin et.al (2014:37) said "the study of internal structure of words and of the rules by which words are formed is morphology."

The field of morphology divided into two main branches, namely inflectional morphology and lexical morphology. Inflectional morphology is concerned with the process of word formation by inflection, while lexical morphology or often referred to as word formation refers to the process of word formation by means of derivation or compounding the researcher would like to do research on affixes in an English because 
readers, especially students often get in problem when they found affixation. Yule (2010:64) said, "Inflectional morphemes are bound morpheme that are used to serve grammatical purpose. The attachment of inflectional morpheme does not create a new word.

The researcher will focus to research inflection of verb and adjective in The Rainbow Troops. Inflection is the formation of new words resulting from a morphemic process that it does not change the class of words. Inflection can also be interpreted as a morphological process that produces different word forms from the same word class. In other words, inflections are forms, which differ from the same class of words. Contrary to derivation, though inflection and derivation are both new word formation resulting from morphemic.

Some of previous research studies related with this research which is used to conduct of this analysis as references. There are: An Analysis of Derivational Affixes in The Land of Five Towers Novel by A. Fuadi Translated by Angie Kilbane was studied by Maharani Sri Aryati (2014). This thesis used descriptive qualitative approach. It has similarity research in finding what kind of affixes in The Rainbow troops Novel. The differences is the researcher focuses in inflectional affixes and how it morphologically can be form, meanwhile Maharani's thesis only focused in finding derivational affixes in the novel. The result of the research found that there are 199 (adjective), 188 (nouns) and 266 (verbs) that have affixes in their root. And An Analysis of Inflectional and Dericational Affixation in Harry Potter and The Philosoper's Stone Novel by J.K. Rowling, was studied by Intan Andini (2019). In this thesis used descriptive method and researched what kind of inflectional and derivational affixes in the Novel. It has similar theme with the researcher. But it only focuses to find the meaning of inflectional and derivational affixation.

Considering statement above, the writer makes a study entitled "An Analysis on Inflectional Affixes in The Rainbow Troops Novel by Andrea Hirata Translated by Angie Kilbane".

\section{Methods}

\section{Research Approach}

In this research, the researcher uses qualitative research, that mean research that produce data, speech, word and behavior that can be observed by the subject itself. And also, descriptive research, it means that the method is intended to make a systematic and accurate description concerning the fact and the features of research data.

\section{Research Technique}

The researcher collects data from novel of The rainbow Troops uses documentation and note taking method. Then, the researcher identifies and classify data and put into category table of inflectional affixes that will be used for data analysis. Sugiyono (2018:125) confirms triangulation is research that use all kind data from various sources. Data triangulation is a method that using multiple data sources and investigators to confirm a guarantee interpretation or conclusion.

The researcher classifies data into category, then analyze them how verb and adjective can be inflected. Then, the researcher defines the function of each category in inflectional affixes, particularly in verb and adjective. At last, the researcher will present the result and give conclusion and suggestion about inflectional affixes, particularly in verbs and adjectives. 
Table 1 Category of Inflectional Affixes

\begin{tabular}{|c|c|c|c|c|}
\hline No & Roof & Roof + Suffix & Word & $\begin{array}{l}\text { Number of } \\
\text { Word } \\
\text { Appearance }\end{array}$ \\
\hline 1 & & & & \\
\hline 2 & & & & \\
\hline 3 & & & & \\
\hline 4 & & & & \\
\hline 5 & & & & \\
\hline
\end{tabular}

Table 2 Recapitulation Data of Inflectional Affixes

\begin{tabular}{clcc}
\hline No & \multicolumn{1}{c}{ Type of inflection affixes } & Frequent & Percentage \\
\hline 1 & Inflectional verb of Past Tense in regular Form & \\
2 & Inflectional verb of Past Tense in irregular Form & \\
3 & Inflectional verb of Past Participle in regular Form & \\
4 & Inflectional verb of Past Participle in irregular Form & in \\
5 & Inflectional verb with suffix (-ing) in Present Participle & \\
6 & Inflectional verb with suffix (-s) in Present in Third Person & \\
7 & Singular & \\
8 & $\begin{array}{l}\text { Inflectional adjective with suffix (-er) in Comparative } \\
\text { Inflectional adjective with suffix (-est) in Superlative } \\
\text { Adjective }\end{array}$ & \\
\hline
\end{tabular}

\section{Result}

The result of this research consists of the types of inflectional affixes in The Rainbow Troops novel by Andrea Hirata translated by Angie Kilbane. Further, the researcher analyzes the types of inflectional affixes by Fromkin et.al and Yule's categories to find what kinds of inflectional affixes that were used in this novel. This research also analyzes the function of inflectional affixes, particularly in inflectional verbs and adjectives.

The data are classified and presented into several tables. The tables consist of four types of inflectional verb and two types of inflectional adjective. The researcher also analyzes the functions of inflectional verbs and adjectives in this novel. As the result of the research finds totally used of the inflectional verbs and adjectives in the novel, as following types that listed:

Table 3 Recapitulation Data of Inflectional Affixes In The Rainbow Troops Novel

\begin{tabular}{clcc}
\hline No & \multicolumn{1}{c}{ Type of inflection affixes } & Frequent & Percentage \\
\hline 1 & Inflectional verb of Past Tense in regular Form & 640 & $44,5 \%$ \\
2 & Inflectional verb of Past Tense in irregular Form & 90 & $6,25 \%$ \\
3 & Inflectional verb of Past Participle in regular Form & 313 & $21,78 \%$ \\
4 & Inflectional verb of Past Participle in irregular Form & 80 & $5,56 \%$ \\
5 & Inflectional verb with suffix (-ing) in Present Participle 235 & $16,35 \%$ in \\
6 & Inflectional verb with suffix (-s) in Present in Third & 30 & $2,09 \%$ \\
& Person Singular & &
\end{tabular}


7 Inflectional adjective with suffix (-er) in Comparative

8 Adjective

Inflectional adjective with suffix (-est) in Superlative

Adjective
20

$1,39 \%$

30

\section{Discussion}

Based on the result in table 3, the researcher finds out total of inflectional affixes based on the scope of research are 1.438 which consist of the inflectional verbs and the inflectional adjectives. The Inflectional verbs with suffix (-ed) in Past Tense with total 640 verbs $(44.5 \%)$ are the most widely used in the novel. The inflectional adjectives with suffix (-er) with total 20 adjectives $(1.39 \%)$ are rarely used in the novel.

The types of inflectional affixes have their own function which were infected with the bound morpheme in their morphological processes. The researcher finds out there are several functions that are used in this novel. The inflectional verbs of past tense consist of regular and irregular form which refers to show their function in forming verb in the past. The inflectional verbs of past participle consist of regular and irregular form which refer to show their several function. They form as a verb in prefect tense, as adjective that modifier noun, and as passive verb. The inflectional verbs of present participle show functions which are as verb-ing in progressive tense, as adjective that modifier noun, and as gerund.

Meanwhile, The inflectional verbs of present for 3rd singular person show its function as verb.Then, The inflectional adjectives show two functions which are comparative degree and superlative degree. These functions are used in the novel that can be studied by reader to enrich their vocabulary.

\section{Conclusion}

From analysis that researcher does, they are many kinds of inflectional affixes in the Rainbow Troops Novel. Based on the scope of problem, the researcher draws conclusion as follow: The types of inflectional affixes were the most frequently used in the Rainbow Troops novel is inflectional verb of past tense in regular form with total 640 (44.5\%), Then the result is followed by the inflectional verbs of past tense in irregular form with total $90(6.25 \%)$. Then, the inflectional verbs of past participle in regular form with total $(21.78 \%)$, which is followed by inflectional verbs of past participle in irregular form with total $80(5.56 \%)$ and the inflectional verbs of present participle with suffix (-ing) with total $235(16.34 \%)$. The next result is inflectional verbs with suffix (-s) in 3rd singular person with total $30(2.09 \%)$. The last are inflectional adjectives with suffix (-er) in comparative adjective with total $20(1.39 \%)$, which is followed by inflectional adjective with suffix (-est) in Superlative adjective with total 30 (2.09\%). The researcher has concluded what kinds the function of inflectional affixes based on their morphological process.

\section{References}

Andini, Intan. (2019). An Analysis of Inflectional and Derivational Affixation in Andini, Intan. (2019). An Analysis of Inflectional and Derivational Affixation in Harry potter and The Philospher's Stone Novel by J.K Rowling. Thesis. Graduate School.Muria Kudus University. Kudus.

Aryati, Maharani Siti. (2014). An Analysis of Derivational affixes in The Land of Five Tower Novel by A Fuadi Translated by Angie Kilbane. Thesis. Graduate School. 
University of Muhammadiyah Palembang. Palembang.

Aronoff, Mark \& Fudeman, Kirsten. (2005). What Is Morphology?. Victoria: Blackwell Publishing.

Cahaya, Ayuci Dwi. (2018). Morphological Analysis of Affixes Used in BBC. Thesis.

Degree of Sarjana.University of Muhammadiyah Sumatera Utara. Medan.

Cuddon,J.A.(2013).Dictionary of Literary Term and Literary

Theory. Sidney:Wiley-Blackwell.

Erlinawati, Fitri Amalia. (2018). Derivational and Inflectional Affixes in @The

GoodQuote's Posts On Instagram. Thesis. Degree of Sarjana. UIN Sunan Ampel University.Surabaya.

Fitryannisa,Pradina. (2017). A Morphological Analysis of The Suffix $\{$-full $\}$ in Forming

New Lexical Categories. Thesis. Sanata Dharma University. Depok

Ford, M.A, Davis, M.H. \& Marslen-Wilson W.D. (2010). Derivational Morphology and

Base Morpheme Frequency. Cambridge : Elsevier Inc.

Fromkin, V., Rodman, R. \& Hyams,N. (2014). An Introduction to Language 7th Edition. USA: PT. Bentang Pusaka.

Gleason, H. A. (1980). An Introduction to Descriptive Linguistics. United State of America : Holt, Rinehart \& Winston, Inc.

Haspelmath, \& Sims. (2010). Understanding Morpholgy. Second Edition.London : Hodder Education Hachette UK Company

Napa, A. Pieter. (1991). Vocabulary Development Skill. Yogyakarta : Kanisius

Nurgiyantoro, B. (2005). Teori Pengkajian Fiksi. Yogyakarta: UGM Press.

O' Grady, William and Dobrovolsky. (1992). An Introduction Contemporary Linguistic Analysis. Toronto: Corp Clark Pitma, Ltd.

Plag, Ingo. (2003). Word-Formation in English. London: Cambridge University Press.

Quinn, E. (2016). A Dictionary of Literary and Thematic Terms. New York :

Facts on File. Inc.

Sugiyono.(2018). Metode Penelitian Pendidikan : Pendekatan Kuantitatif,

Kualitatif dan R\&D. Bandung : UPI

Yule, G. (2010). The Study of Language, Fourth Edition .United State of America : Cambridge University Press 